\title{
ANALYSIS OF PLANNING, IMPLEMENTATION, ASSESSMENT OF LEARNING FROM HOME STRATEGIES DURING THE COVID-19 PANDEMIC IN PRIVATE ELEMENTARY SCHOOLS
}

\author{
Beti Istanti Suwandayani ${ }^{1}$, Dyah Worowirastri Ekowati ${ }^{2}$, \\ Sony Darmawan ${ }^{3}$, Ari Dwi Haryono ${ }^{4}$ \\ Universitas Muhammadiyah Malang, Indonesia ${ }^{1,2}$ \\ Muhammadiyah 9 Elementary School, Malang, Indonesia ${ }^{3}$, \\ Bani Hasyim Islamic Elementary School, Malang, Indonesia ${ }^{4}$ \\ E-mail: beti@umm.ac.id ${ }^{1}$,worowirastri@umm.ac.id ${ }^{2}$, \\ sonydarmawan79@gmail.com ${ }^{3}$, aridwiharyono12@gmail.com ${ }^{4}$
}

DOI: 10.14421/al-bidayah.v13i1.623

\begin{abstract}
The impact of the COVID-19 virus is so significant. Efforts have been taken to handle the impacts on various fields, including in-field education. The Indonesian government has established three policies in education, one of which is learning from home. This article analyzes the planning, implementation, assessment of learning from home strategies during the COVID-19 pandemic in private elementary schools. The research was conducted qualitatively, and the type of research was descriptive. The instruments of this research were interviews, indirect observations, and documentation studies. The research subjects were two principals, two teachers, two students, two guardians of students from each elementary school, i.e., Muhammadiyah 9 Elementary School and Bani Hasyim Islamic Elementary school, both in Malang, East Java, Indonesia. Among the research subjects, the Principal of each school is the key informant in this study. The results of the analysis show that the lesson planning already includes the use of lesson plans. However, communication with students and parents is done through PANDAWA applications and daily learning scenarios, which contain materials, teaching materials, LKPD, and assessment questions. The implementation of learning is carried out synchronously and asynchronously. The learning assessment is conducted by sending questions using various applications such as Edmodo, Quilgo, Google Classroom, and the PANDAWA website. Various forms of innovation in learning services while learning from home are key parts in improving the quality of private elementary schools.
\end{abstract}

Keywords: assessment; COVID-19 pandemic; implementation; learning from home strategies; planning

\section{INTRODUCTION}

The emergence of 2019-nCoV has attracted global attention. WHO declared Covid-19 a public health emergency of international concern on January 30, as did Indonesia. Based on data in Indonesia as of July 15, 2021, the number of positive cases was 2,670,046 people, 2,157,363 people recovered, and 69,210 people died (covid19.go.id) ${ }^{1}$. The increase in the number of Covid-19 cases has an impact on various

${ }^{1}$ A. Spinelli and G. Pellino, "COVID-19 Pandemic: Perspectives on an Unfolding Crisis," British Journal of Surgery 107, no. 7 (2020): 785-87, https://doi.org/10.1002/bjs.11627; Alireza Hamidian Jahromi, Samira Mazloom, and David H. Ballard, "What the European and American Health Care Systems Can Learn from China COVID-19 Epidemic; Action Planning Using Purpose Designed Medical Telecommunication, Courier Services, Home-Based Quarantine, and COVID-19 Walk-in Centers," Immunopathologia Persa 6, no. 2 (2020): e17-e17, https://doi.org/10.34172/ipp.2020.17; Chavez Phelps and Linda L. Sperry, "Children and the COVID-19 Pandemic," Psychological Trauma: Theory, Research, Practice, and Policy 12 (2020): 73-75, https://doi.org/10.1037/tra0000861. 
sectors. One of them is in the field of education. The Covid-19 pandemic at this time is demands teachers to have a supportive learning strategy while the world of education in the current era has experienced very rapid progress along with the advancement of information technology. Therefore, teachers are implementing online learning as a solution during the Covid-19 pandemic in Indonesia ${ }^{2}$.

However, carrying out online learning is not an easy job ${ }^{3}$. Communityimplemented home-based learning activities cause students and teachers to lose opportunities to interact with each other to establish social relationships, cultivate solidarity among fellow human beings, lose caring and empathy. Learning from home is certainly different from learning at school, where one can easily find learning tools and instructional media are available to facilitate students in understanding the material.

Online learning has many shortcomings, especially for elementary school students. These shortcomings are due to the limited knowledge of the technology being one of the common problems felt among rural communities, especially the limited knowledge of parents as facilitators who must support student learning activities ${ }^{4}$. Preliminary observations conducted by researchers, elementary schools in Malang have implemented online learning, in which students' learning process is implemented at home. Learning from home requires teachers to do different strategies from learning that is usually done in school. This research is vital in response to this phenomenon because it describes planning, implementation, and evaluation in the online learning process.

Online research in the context of the impact of its implementation has been conducted $^{5}$. The two studies focus on the implementation and impact of learning in

${ }^{2}$ Rasmitadila et al., "The Perceptions of Primary School Teachers of Online Learning during the Covid-19 Pandemic Period: A Case Study in Indonesia," Journal of Ethnic and Cultural Studies 7, no. 2 (2020): 90-109, https://doi.org/10.29333/ejecs/388; Leila Zuo, Dawn Dillman, and Amy Miller Juvé, "Learning at Home during COVID-19: A Multi-Institutional Virtual Learning Collaboration," Medical Education 54, no. 7 (2020): 664-65, https://doi.org/10.1111/medu.14194; Abbey R. Masonbrink and Emily Hurley, "Advocating for Children during the COVID-19 School Closures," Pediatrics 146, no. 3 (2020), https://doi.org/10.1542/PEDS.2020-1440.

3 Asrilia Kurniasari, Fitroh Setyo Putro Pribowo, and Deni Adi Putra, "Analisis Efektivitas Pelaksanaan Belajar dari Rumah (BDR) Selama Pandemi Covid-19," Jurnal Review Pendidikan Dasar : Jurnal Kajian Pendidikan dan Hasil Penelitian 6, no. 3 (September 10, 2020): 246-53, https://doi.org/10.26740/jrpd.v6n3.p246-253.

${ }^{4}$ Nusrat Jahan Rafique Ansari et al., "Study of Parental Perceptions on Health \& Social Needs of Children with Neuro-Developmental Disability and It's Impact on the Family," Journal of Clinical and Diagnostic Research 10, no. 12 (2016): SC16-20, https://doi.org/10.7860/JCDR/2016/22538.9039.

5 Ilkogretim Online, Elementary Education Online, and Iksal Bostan, "Implementation of Technology Enhanced Activities for Teaching Slope in Daily Life Situations," Illkögretim Online 20, no. 1 (2021): 1-19, https://doi.org/10.17051/ilkonline.2021.01.011. 
primary schools. The other research is ${ }^{6}$ which focuses on the model of online learning in primary schools. Thus, this study differs from previous studies in terms of exposure to the research context as this study deals with the planning, implementation, and evaluation of online learning. Based on the above, researchers hope that this study's research data and findings contribute to optimizing online learning conducted at home.

\section{RESEARCH METHODS}

The research method is descriptive with a qualitative research approach. Qualitative data is a source of reasonable and process human descriptions and explanations. With qualitative data, both the chronology and the interpretation can be clarified. The subjects of this study were two school principals, two teachers, two students, and two guardians of students of Muhammadiyah 9 Elementary School and Bani Hasyim Elementary School, both in the city of Malang, East Java, Indonesia. Among the research subjects, the Principal of each school was the key informant in this study. The study focused on describing the planning, implementation, assessment of learning from home. As is common in descriptive qualitative studies, data collection in this study used open structured interviews ${ }^{7}$. The interview process was carried out online over a WhatsApp group (WAG). In addition, data collection was also carried out through observation and documentation during the COVID-19 pandemic.

Data were analyzed qualitatively. The first step is data coding ${ }^{8}$. The coding was done directly from field notes, not from "public" articles, without much criticism and refinement". The coding was recorded as "Data collection/research subject/date". For example, the code W/KS/121220 means an interview with the Principal of the School (as "KS" stands for "Kepala Sekolah" or "School Principal"). The second step was to write and reflect in-depth on the data. The third step was sorting the data based on content and information patterns. Then, the next step was to look for similarities and differences for further analysis. Then, the fifth step was to draw generalizations from the results. At this

\footnotetext{
${ }^{6}$ Manasi Echaune, Judah M. Ndiku, and Anthony Sang, "Parental Involvement in Homework and Primary School Academic Performance in Kenya," Journal of Education and Practice 6, no. 9 (2015): 4653, https://eric.ed.gov/?id=EJ1082463.

${ }^{7}$ John W. Creswell and Vicki L. Plano Clark, Designing and Conducting Mixed Methods Research, Third Edition (Thousand Oaks, California: SAGE, 2018), 849.

8 Creswell and Clark. "Praise for the Third Edition," 2018.

${ }^{9}$ Mohammad Mahpur, "Memantapkan Analisis Data Kualitatif Melalui Tahapan Koding” (Fakultas Psikologi Universitas Islam Negeri Malang, Indonesia, 2017), http://repository.uin-malang.ac.id/800/.
} 
stage, various data were grouped into several categories. Thus, the large amount of data obtained could be reduced to a small number of logical units. Then, all the logical units were linked to each other to form a framework. This framework was used as the basis for the formulation of general concepts. Finally, the sixth step connected the generalization results with references and theory. At this step, any general concept resulting from the fifth step was linked to existing concepts or results from previous studies

\section{RESULTS AND DISCUSSION RESULT}

This learning from the Home strategy is part of Circular Letter Number 4 of 2020 dated March 24, 2020, namely Learning from Home. The following describes the planning, implementation, and assessment of the Learning from Home strategy in the two primary schools.

\section{Muhammadiyah 9 Elementary School}

Muhammadiyah 9 Elementary School is a private school located in the city of Malang and is a school under the administration of the University of Muhammadiyah Malang. This school, which is located in the heart of Malang, has a total of 675 students. As a private school with the most significant number of students in the city of education, the current conditions require schools to continue innovating in providing educational services. The innovations carried out will be described in each part of the planning, implementation, and assessment carried out by Muhammadiyah 9 Elementary School's explained below.

\section{Lesson Planning}

Lesson planning at Muhammadiyah 9 Elementary School is considered part of a learning program that includes a discussion unit for one or more meetings. Therefore, in this article, the planning in question will be explained. So are the Learning Implementation Plan and daily learning scenarios designed by the teacher. Lesson plans are used as a reference for teachers in carrying out learning both online and offline. Meanwhile, the teacher uses the daily learning scenario to inform parents and guardians of the lesson plans and give direction for students during Learning from Home. 
The lesson plan prepared by the teacher consists of several components. These components consist of (1) learning objectives, (2) learning materials/materials, (3) learning methods, (4) learning media, (5) learning resources, and (6) assessment of learning outcomes. Figure 1 shows the components of the lesson plan.

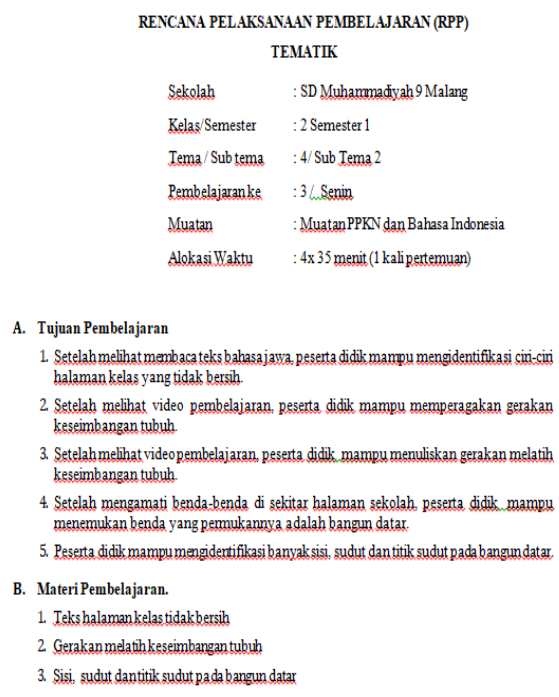

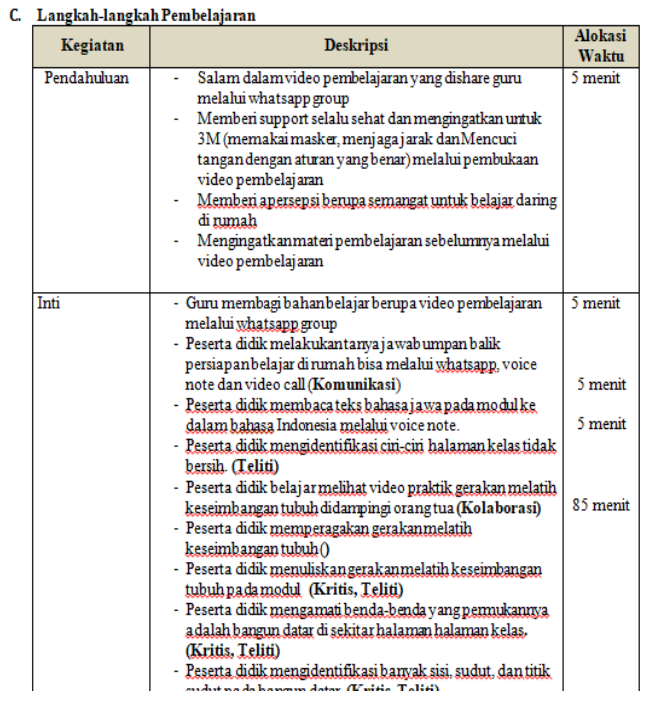

Figure 1

Based on the picture above, it appears that the lesson plans used by the teacher have facilitated students during learning from home, i.e., by showing the use of social media such as Whatsapp as a means of communication. In addition, the teacher has prepared to learn videos that serve as learning materials, media, and directions to complete worksheets for every 1 lesson used by students during Learning From Home. However, to facilitate communication between teachers and parents, teachers also prepare daily learning scenarios. This daily learning scenario is the essence of the material or activities that students will carry out. Figure 2 shows the daily learning scenario. 


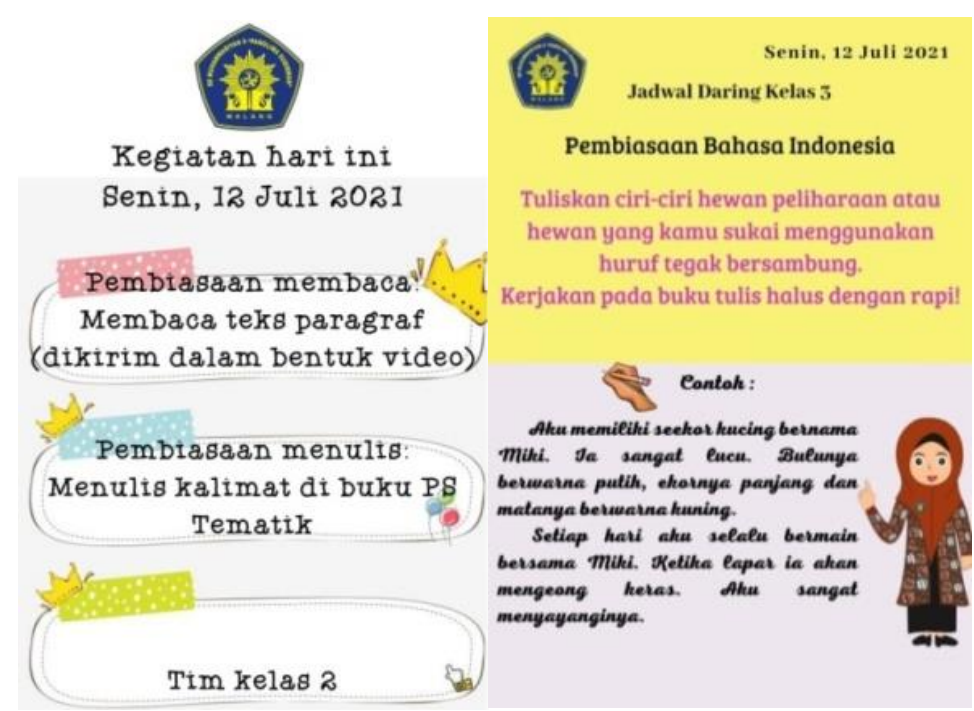

Figure 2

Daily Learning Scenario

In the daily learning scenario above, each grade level is different. This difference is because the school gives each teacher the liberty to realize daily learning scenarios according to grade level as long as they refer to the previously prepared lesson plans. Therefore, the daily learning scenarios distributed to parents and guardians of students in each parallel class have the same template. In addition, there are not only similarities in daily learning scenarios and similarities in materials, media, student worksheets (or called LKPD in Indonesia), and learning assessments. On the other hand, this daily learning scenario will be different between each grade level. It can be seen from the differences in the form and content of the material and other attachments. Teachers teach according to lesson plans; students learn by referring to daily learning scenarios. Meanwhile, parents feel comfortable because learning and student assignments are clear, measurable, and effective.

\section{Implementation of learning}

The implementation of learning during Learning from Home at Muhammadiyah 9 Elementary School refers to the lesson plans prepared previously, namely synchronously and asynchronously. One of the keys to learning during this Learning from Home lies in the virtual mode used. This virtual mode is because learning is still carried out using WhatsApp Groups (WAG), Google Meet, Zoom, and other applications. Every effective school day, the learning from home process begins with sending daily learning 
scenarios by the teacher at night or the day before in the WA group. Figure 3 shows an example of sending a learning package.

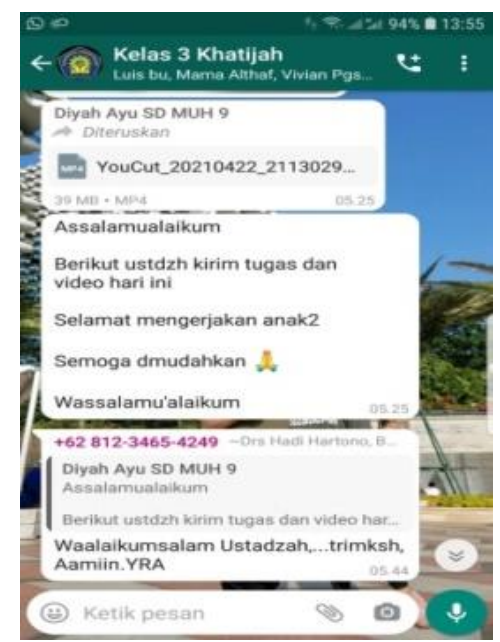

Figure 3

Sending assignments via WAG while learning from home

After getting the learning materials, students begin studying asynchronously. Study time for the students is more flexible and follows daily learning scenarios. Student's works are then sent back to the teacher by 8 PM WIB (Western Indonesian Time). Discussions related to the material being studied are carried out synchronously using the Google Classroom application, Zoom, or WA video calls in groups. The teacher decided on the group members. Thus, each lesson can be completed.

\section{Learning Assessment}

In terms of learning assessment during Learning from Home, three assessment areas were carried out: cognitive, affective, and skill assessments. Specifically, skill and affective assessments are carried out during asynchronous processes or through prayer monitoring books, rote monitoring, and photo or video documentation of student activities. In the context of effective and skill assessment during Learning from Home, this Elementary School owned by Muhammadiyah (one of the most prominent Islamic organizations in Indonesia) emphasizes Islamic life skills and character development. In addition, in the cognitive assessment process, Muhammadiyah 9 Elementary School has used various applications, including Quilgo, Edmodo, Google Form, and Youtube. These various applications are sent in the form of a link to the parents' WA group. Before the cognitive assessment is carried out, each student is allowed to practice. Figure 4 shows an example of practice questions before the cognitive assessment test. 


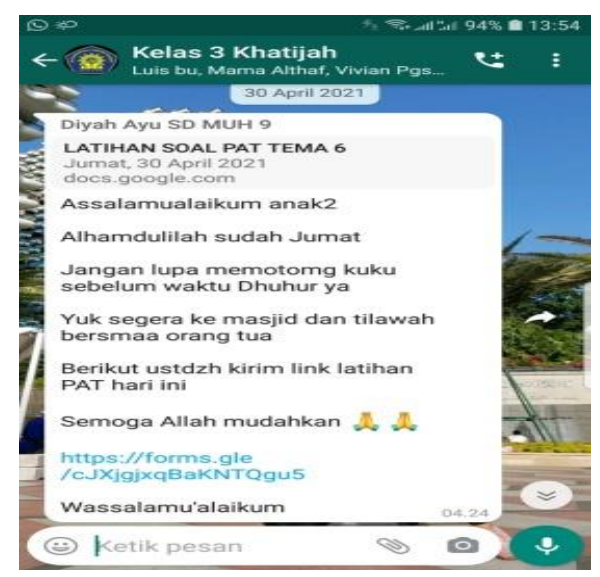

Figure 4

Examples of practice questions before the cognitive assessment test

This cognitive assessment also does not always answer questions, and it can also be in the form of questions given during WA video calls per group or during synchronous discussions.

\section{Bani Hasyim Elementary School, Malang Regency}

Based on the results of observations at Bani Hasyim Elementary School, Malang Regency, information was obtained from school strategies during Learning From Home, which included planning, implementation, and assessment carried out by schools. The explanation is as follows

\section{Planning}

This elementary school in Malang Regency carries out learning by giving assignments and activities that can be completed at home. The form of lesson planning is designed by government policy, namely in a learning implementation plan. However, the embodiment of this learning plan is presented in a guidebook, namely PANDAWA (Student Online Guide). PANDAWA is implemented as a form of website-based learning from home strategy. On the website, the school has organized learning activities using PANDAWA. Figure 5 shows the PANDAWA applications. 


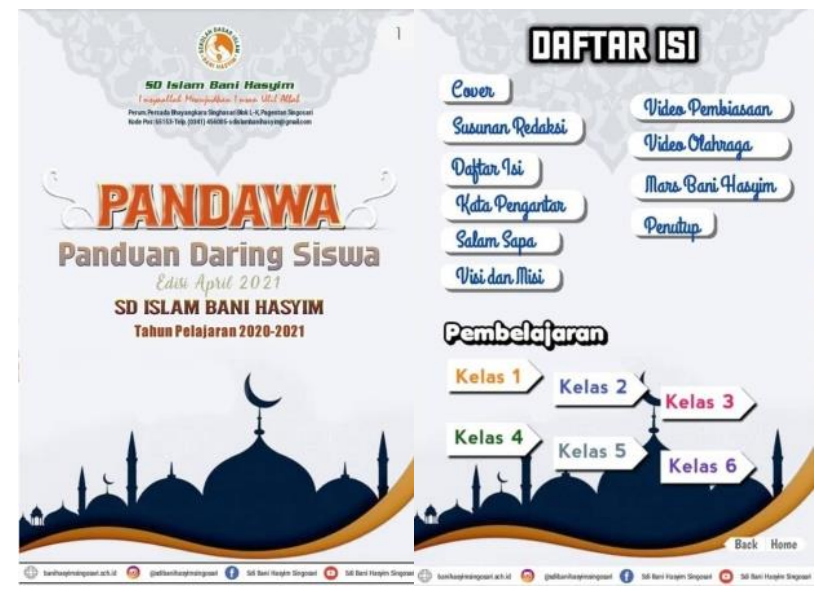

Figure 5

PANDAWA Applications

Based on the results of an interview with the Principal of the Bani Hasyim elementary school on April 20, 2021, it is known that the teacher team has prepared lesson plans for each grade level. Planning is done every month, so PANDAWA will also change every month. A complete online learning plan is explained in the guide, which includes cover, editorial composition, table of contents, introduction, greetings, vision, mission, habituation videos, sports videos, Bani Hasyim march, class 1-6 learning packages, and closings. Through PANDAWA, communication and interaction between schools, teachers, students, and their parents go well, even though students learn from home.

\section{Implementation}

As the plan stated in PANDAWA, the teacher carries out learning according to the learning scenario. The implementation of learning from home follows the directions of PANDAWA. Therefore, teachers, students, and parents know when to conduct synchronous or asynchronous learning strategies. There are materials, teaching materials, worksheets, assessment questions, and synchronous and asynchronous activity schedules in each lesson. When synchronized, Bani Hasyim Elementary School uses a school website specially designed to support PANDAWA. The school calls it the PANDAWA application. The use of the PANDAWA application also delivers a series of paperless and environmentally friendly learning. The time required will also be more efficient for delivery tasks, submission of tasks, and questions analysis.

PANDAWA application also requires teachers to be creative in delivering lessons. This application is what makes parents believe that learning from home does not reduce the quality of learning. Although on the other hand learning from home requires many 
data packages because it has to guide the stages of learning. However, this research has proved that the student's work satisfies the parents of the student. Figure 6 shows the learning process from home through independent assignments.

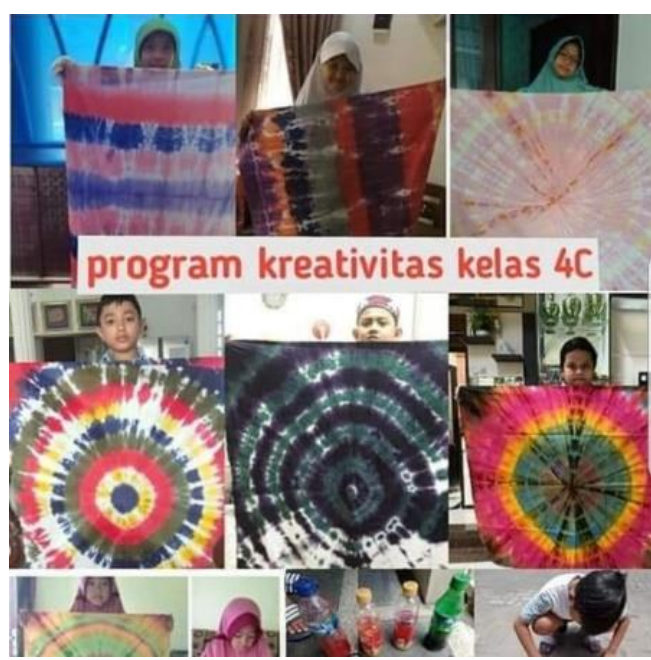

Figure 6

Learning process from home through independent assignments

Figure 6 shows that students can work according to what was designed through the PANDAWA application. Based on the interviews with Elementary School principals at the end of March 2021, it is known that during learning, students can easily access the application. Learning strategies from home by using this application is very helpful in the process of achieving learning objectives.

\section{Learning Assessment}

The results of assessments for assignments that have been collected can also be seen in this PANDAWA application. Through the same application, students know the score of each assignment. When the teacher inputs the score in the application, students and parents can easily find out the assessment results. Therefore, this application is beneficial when studying from home. However, the Principal, students, teachers, and guardians of students have high hopes that face-to-face learning can be carried out as soon as possible. This is because, with face-to-face learning, students can interact directly and support student development as they are at an age where development also happens through playing. 


\section{DISCUSSION}

Muhammadiyah 9 Elementary School and Bani Hasyim Elementary School are the two leading private schools in their respective regions. As private schools, both schools should provide quality learning services. One of the manifestations of quality learning services can be seen in the planning, implementing, and assessing learning during learning from home ${ }^{10}$. Both schools have the same lesson plans during learning from home, especially in terms of their preparation. The lesson plans that the two schools have designed have provided services to teachers and students that facilitate the learning process. At Muhammadiyah 9 Elementary School, it is realized that daily learning scenarios are distributed using social media ${ }^{11}$. Each scenario that is distributed is a simplification of the lesson plans every week, usually every Friday. However, to improve it, teachers distribute daily learning scenarios every morning before studying. In the daily learning scenarios, information on the time to perform synchronous and asynchronous activities is also provided ${ }^{12}$. This scenario is done to evaluate activities daily.

The learning implementation at Muhammadiyah 9 Elementary School is different from how Bani Hasyim Elementary School accommodates the learning plan through PANDAWA application. The learning plan is given every month. Through this plan, teachers, students, and their parents know about learning activities next month. When using this application, students cannot change daily learning activities. Therefore, new information or incidents emerge that need to be addressed urgently; it cannot be done.

Based on the description above, it appears that learning planning as a system is an arrangement of resources and procedures to drive learning. The development of a learning system through a systematic process is then implemented in the planning system. In practice, planning that involves technology is a plan that encourages techniques that can

\footnotetext{
${ }^{10}$ Mary-Anne Jasinski, "Helping Children to Learn at Home: A Family Project to Support Young English-Language Learners," TESL Canada Journal $29 \quad$ (2012): 224, https:/doi.org/10.18806/tesl.v29i0.1119; Kurniasari, "Analisis Efektivitas Pelaksanaan Belajar Dari Rumah (Bdr) Selama Pandemi Covid-19."

${ }^{11}$ Hamdan Husein Batubara and Dessy Noor Ariani, "Workshop Penggunaan Google Form Sebagai Media Evaluasi Pembelajaran Pada Dosen-Dosen Fakultas Studi Islam," Jurnal Pengabdian Al-Ikhlas Universitas Islam Kalimantan Muhammad Arsyad Al Banjary 2, no. 1 (Oktober 2016), https://doi.org/10.31602/jpai.v2i1.961.

12 Manasi Echaune, Judah M Ndiku, and Anthony Sang, "Parental Involvement in Homework and Primary School Academic Performance in Kenya" 6, no. 9 (2015): 46-54; Ella Hafermalz and Kai Riemer, "Productive and Connected While Working from Home: What Client-Facing Remote Workers Can Learn from Telenurses about 'Belonging through Technology," European Journal of Information Systems 00, no. 00 (2020): 1-11, https://doi.org/10.1080/0960085X.2020.1841572.
} 
develop cognitive behavior and constructive theories for solutions and learning problems, especially for private schools ${ }^{13}$. Therefore, learning planning becomes a reflection of the quality of learning that will be carried out. For private schools, this is very important and meaningful ${ }^{14}$.

In the implementation of learning, synchronous and asynchronous activities are used. In this case, learning does not only depend on the quality of the network. However, this learning scenario accommodated students in learning ${ }^{15}$. This scenario follows the government's Circular Letter Number 15/2020 concerning Guidelines for Organizing Learning from Home in the Emergency Period during the Spread of COVID-19. The circular stated that the application of learning from home aims to ensure the fulfillment of students' rights to obtain educational services during the COVID-19 emergency, protect education units from the adverse effects of COVID-19, prevent the spread and transmission of COVID-19 in education units, and ensure the fulfillment of psychosocial support for educators, students, and parents/guardians. Learning activities in both schools are carried out from their respective homes, assisted by technology through Zoom, Google Meet, Google Classroom, or PANDAWA application ${ }^{16}$.

The forms of assessment carried out by teachers in both schools are closely related to teacher resources and school policies. Both schools are Islamic schools, so that the assessments carried out are not only in the cognitive, affective, and psychomotor domains.

${ }^{13}$ Rusydi Ananda, Perencanaan Pembelajaran, Ed. Amiruddin, 1st Ed. (Medan, Sumatera Utara: Lembaga Peduli Pengembangan Pendidikan Indonesia (LPPPI), 2019), http://repository.uinsu.ac.id/6719/1/5. PERENCANAAN PEMBELAJARAN \%28BUKUPENULIS\%29.pdf; Mary-Anne Jasinski, "Helping Children to Learn at Home: A Family Project to Support Young English-Language Learners," TESL Canada Journal 29 (2012): 224-30.

${ }^{14}$ Septya Nugrahanto and Darmiyati Zuchdi, "Indonesia PISA Result and Impact on The Reading Learning Program in Indonesia" (International Conference on Interdisciplinary Language, Literature and Education (ICILLE 2018), Atlantis Press, 2019), 373-77, https://doi.org/10.2991/icille-18.2019.77; Fauzi Sayuti, "Peran Kepala Sekolah Dalam Peningkatan Mutu Pendidikan Islam," Fikrotuna 3, no. 1 (2016), https://doi.org/10.32806/jf.v3i1.2714.

15 Jasinski, "Helping Children to Learn at Home"; Katharina Völker, "Nasr Hamid Abu Zayd's Philosophy on Islam and Education," in International Handbook of Philosophy of Education, ed. Paul Smeyers, Springer International Handbooks of Education (Cham: Springer International Publishing, 2018), 17-28, https://doi.org/10.1007/978-3-319-72761-5_3.

${ }^{16}$ Hafermalz and Riemer, "Productive and Connected While Working from Home: What ClientFacing Remote Workers Can Learn from Telenurses about 'Belonging through Technology"'; Nuhyal Ulia and Imam Kusmaryono, "Mathematical Disposition of Students', Teachers, and Parents in Distance Learning: A Survey," Premiere Educandum : Jurnal Pendidikan Dasar Dan Pembelajaran 11, no. 1 (2021): 147, https://doi.org/10.25273/pe.v11i1.8869. 
Assessments also cover the development of life skills and characters ${ }^{17}$. The study discovered that mothers, teachers, and the community provided a more appropriate understanding of children and instilled the importance of being grateful to God Almighty, and internalizing egalitarian, humanitarian attitudes, namely respect, care, share, strengthen hearts, and put forward identity so that life becomes useful ${ }^{18}$. Thus, the complete learning service is carried out well even though it is learning from home.

\section{CONCLUSION}

Based on the results of the research above, it is known that the planning, implementation, assessment of learning during the learning strategy from home in Muhammadiyah 9 Elementary School and Bani Hasyim Elementary School in Malang, East Java, Indonesia is one of the benchmarks for the quality of private schools. Learning planning is realized through a learning implementation plan in compliance with government regulations. However, both schools have innovations to bridge communication between students and parents, namely in daily learning scenarios and PANDAWA application. Daily learning scenarios contain teaching materials, learning media, teaching materials, worksheets, and assessment questions. In contrast, the PANDAWA application consists of cover, editorial composition, table of contents, introduction, greetings, vision, mission, habit building videos, sports videos, Bani Hasyim march, class 1-6 learning packages, and closings. The learning is implemented synchronously and asynchronously. Whether using the PANDAWA application or zoom meeting, google meeting, or other social media. Assessment of learning while studying from home is done by sending questions using various Edmodo, Quilgo, Google Classroom, and PANDAWA applications. Various forms of innovation in learning services while learning from home are key steps in improving the quality of private elementary schools.

17 Astrid Varhol, Ove Gunnar Drageset, and Monica Nymoen Hansen, "Discovering Key Interactions. How Student Interactions Relate to Progress in Mathematical Generalization," Mathematics Education Research Journal, no. 1 (2020), https://doi.org/10.1007/s13394-020-00308-z.

${ }^{18}$ Asfiati Asfiati et al., "Internalization Of Humanistic Values For Early Ages Children In Facing Pandemic COVID-19," Al-Bidayah: Jurnal Pendidikan Dasar Islam 12, no. 2 (2020): 297-316, https://doi.org/10.14421/al-bidayah.v12i2.578; Ali Mudlofir, "Pendidikan Karakter: Konsep Dan Aktualisasinya Dalam Sistem Pendidikan Islam," Nadwa 7, no. 2 (2016): 229, https://doi.org/10.21580/nw.2013.7.2.560; Nurma Cahyani and Ali Mustadi, "Learning Motivation of Elementary School Children: Is It Possible to Be Increased Using the Teams Games Tournament Model?," Al-Bidayah: Jurnal Pendidikan Dasar Islam 12, no. 2 (2020): 183-98, https://doi.org/10.14421/albidayah.v12i2.583. 


\section{ACKNOWLEDGMENTS}

The researcher would like to thank the University of Muhammadiyah Malang for supporting the collaboration with elementary schools. In addition, the researchers would like to thank the principals and teachers of SD Muhammadiyah 9 Malang City and SD Bani Hasyim Malang Regency who have assisted in providing data and information for the purpose of this study.

\section{DECLARATION OF CONFLICTING INTERESTS}

This article is compiled based on actual research procedures. The author/s declared no potential conflicts of interest with respect to the research, authorship, and/or publication of this article.

\section{FUNDING}

The institution or organization that has provided funding for the research and publication of this article is Directorate of Research and Community Service, University of Muhammadiyah Malang. Research costs are sourced from the Education Development Fund Budget (DPP) University of Muhammadiyah Malang based on The Decree of The Assistant Rector I Number: E.2.A/238/BAA-UMM/III/2020

\section{ORCID iD}

Beti Istanti Suwandayani

(iD) https://orcid.org/0000-0003-2678-6147

Dyah Worowirastri Ekowati

iD https://orcid.org/0000-0002-6241-1273

Sony Darmawan

Ari Dwi Haryono

\section{REFERENCES}

Ananda, Rusydi. Perencanaan Pembelajaran, Ed. Amiruddin, 1st Ed. Medan, Sumatera Utara: Lembaga Peduli Pengembangan Pendidikan Indonesia (LPPPI), 2019. http://repository.uinsu.ac.id/6719/1/5. PERENCANAAN PEMBELAJARAN \%28BUKU-PENULIS\%29.pdf.

Ansari, Nusrat Jahan Rafique, Ramchandra Keshav Dhongade, Preeti Sagar Lad, Ashwin Borade, Y. G. Suvarna, Vishal Yadav, Ashwini Mehetre, and Rahul Kulkarni. "Study of Parental Perceptions on Health \& Social Needs of Children with NeuroDevelopmental Disability and It's Impact on the Family." Journal of Clinical and Diagnostic Research 10, no. $12 \quad$ (2016): SC16-20. https://doi.org/10.7860/JCDR/2016/22538.9039. 
Asfiati, Asfiati, Sutrisno Sutrisno, Nur Imam Mahdi, and Muhammad Aswin. "Internalization Of Humanistic Values For Early Ages Children In Facing Pandemic COVID-19.” Al-Bidayah: Jurnal Pendidikan Dasar Islam 12, no. 2 (2020): 297-316. https://doi.org/10.14421/al-bidayah.v12i2.578.

Batubara, Hamdan Husein, and Dessy Noor Ariani. "Workshop Penggunaan Google Form Sebagai Media Evaluasi Pembelajaran Pada Dosen-Dosen Fakultas Studi Islam." Jurnal Pengabdian Al-Ikhlas Universitas Islam Kalimantan Muhammad Arsyad Al Banjary 2, no. 1 (Oktober 2016). https://doi.org/10.31602/jpai.v2i1.961.

Cahyani, Nurma, and Ali Mustadi. "Learning Motivation of Elementary School Children: Is It Possible to Be Increased Using the Teams Games Tournament Model?" AlBidayah: Jurnal Pendidikan Dasar Islam 12, no. 2 (2020): 183-98. https://doi.org/10.14421/al-bidayah.v12i2.583.

Creswell, John W., and Vicki L. Plano Clark. Designing and Conducting Mixed Methods Research, Third Edition. Thousand Oaks, California: SAGE, 2018.

Echaune, Manasi, Judah M. Ndiku, and Anthony Sang. "Parental Involvement in Homework and Primary School Academic Performance in Kenya." Journal of Education and Practice 6, no. 9 (2015): 4653.https://eric.ed.gov/?id=EJ1082463.

Hafermalz, Ella, and Kai Riemer. "Productive and Connected While Working from Home: What Client-Facing Remote Workers Can Learn from Telenurses about 'Belonging through Technology."' European Journal of Information Systems 00, no. 00 (2020): 1-11. https://doi.org/10.1080/0960085X.2020.1841572.

Hamidian Jahromi, Alireza, Samira Mazloom, and David H. Ballard. "What the European and American Health Care Systems Can Learn from China COVID-19 Epidemic; Action Planning Using Purpose Designed Medical Telecommunication, Courier Services, Home-Based Quarantine, and COVID-19 Walk-in Centers." Immunopathologia Persa 6, no. 2 (2020): e17-e17. https://doi.org/10.34172/ipp.2020.17.

Jasinski, Mary-Anne. "Helping Children to Learn at Home: A Family Project to Support Young English-Language Learners." TESL Canada Journal 29 (2012): 224. https://doi.org/10.18806/tesl.v29i0.1119.

Kurniasari, Asrilia, Fitroh Setyo Putro Pribowo, and Deni Adi Putra. “Analisis Efektivitas Pelaksanaan Belajar dari Rumah (BDR) Selama Pandemi Covid-19.” Jurnal Review Pendidikan Dasar : Jurnal Kajian Pendidikan dan Hasil Penelitian 6, no. 3 (September 10, 2020): 246-53. https://doi.org/10.26740/jrpd.v6n3.p246-253.

Mahpur, Mohammad. "Memantapkan Analisis Data Kualitatif Melalui Tahapan Koding." Fakultas Psikologi Universitas Islam Negeri Malang, Indonesia, 2017. http://repository.uin-malang.ac.id/800/.

Masonbrink, Abbey R., and Emily Hurley. "Advocating for Children during the COVID19 School Closures." Pediatrics 146, no. 3 (2020). https://doi.org/10.1542/PEDS.2020-1440. 
Mudlofir, Ali. "Pendidikan Karakter: Konsep Dan Aktualisasinya Dalam Sistem Pendidikan Islam." Nadwa 7, no. 2 (2016): 229. https://doi.org/10.21580/nw.2013.7.2.560.

Nugrahanto, Septya, and Darmiyati Zuchdi. "Indonesia PISA Result and Impact on The Reading Learning Program in Indonesia," 373-77. Atlantis Press, 2019. https://doi.org/10.2991/icille-18.2019.77.

Online, Ilkogretim, Elementary Education Online, and Iksal Bostan. "Implementation of Technology Enhanced Activities for Teaching Slope in Daily Life Situations." $\begin{array}{llllll}\text { Ilkögretim } & \text { Online } & 20, & \text { no. } & 1 & \text { (2021): }\end{array}$ https://doi.org/10.17051/ilkonline.2021.01.011.

Phelps, Chavez, and Linda L. Sperry. "Children and the COVID-19 Pandemic." Psychological Trauma: Theory, Research, Practice, and Policy 12 (2020): 7375. https://doi.org/10.1037/tra0000861.

Rasmitadila, Rusi Rusmiati Aliyyah, Reza Rachmadtullah, Achmad Samsudin, Ernawulan Syaodih, Muhammad Nurtanto, and Anna Riana Suryanti Tambunan. "The Perceptions of Primary School Teachers of Online Learning during the Covid-19 Pandemic Period: A Case Study in Indonesia." Journal of Ethnic and Cultural Studies 7, no. 2 (2020): 90-109. https://doi.org/10.29333/ejecs/388.

Sayuti, Fauzi. "Peran Kepala Sekolah Dalam Peningkatan Mutu Pendidikan Islam." Fikrotuna 3, no. 1 (2016). https://doi.org/10.32806/jf.v3i1.2714.

Spinelli, A., and G. Pellino. "COVID-19 Pandemic: Perspectives on an Unfolding Crisis." British Journal of Surgery 107, no. 7 (2020): 785-87. https://doi.org/10.1002/bjs.11627.

Ulia, Nuhyal, and Imam Kusmaryono. "Mathematical Disposition of Students', Teachers, and Parents in Distance Learning: A Survey." Premiere Educandum: Jurnal Pendidikan Dasar Dan Pembelajaran 11, no. 1 (2021): 147. https://doi.org/10.25273/pe.v11i1.8869.

Varhol, Astrid, Ove Gunnar Drageset, and Monica Nymoen Hansen. "Discovering Key Interactions. How Student Interactions Relate to Progress in Mathematical Generalization." Mathematics Education Research Journal, no. 1 (2020). https://doi.org/10.1007/s13394-020-00308-z.

Völker, Katharina. "Nasr Hamid Abu Zayd's Philosophy on Islam and Education.” In International Handbook of Philosophy of Education, edited by Paul Smeyers, 1728. Springer International Handbooks of Education. Cham: Springer International Publishing, 2018. https://doi.org/10.1007/978-3-319-72761-5_3.

Zuo, Leila, Dawn Dillman, and Amy Miller Juvé. "Learning at Home during COVID-19: A Multi-Institutional Virtual Learning Collaboration." Medical Education 54, no. 7 (2020): 664-65. https://doi.org/10.1111/medu.14194. 